\title{
BIBECHANA
}

ISSN 2091-0762 (Print), 2382-5340 (Online)

Journal homepage: http://nepjol.info/index.php/BIBECHANA

Publisher: Department of Physics, Mahendra Morang A.M. Campus, TU, Biratnagar, Nepal

\section{Synthesis of antioxidative anthraquinones as potential anticancer agents}

\author{
Richa K. Gupta ${ }^{1,2}$, Ganesh M. S. Thakuri', Gan B. Bajracharya ${ }^{1^{*}}$, Ram Narayan Jha ${ }^{3^{*}}$ \\ ${ }^{1}$ Laboratory of Catalysis and Frontier Molecules, Faculty of Science, Nepal Academy of Science and \\ Technology (NAST), Khumaltar, Lalitpur, Nepal \\ ${ }^{2}$ Central Department of Chemistry, Tribhuvan University, Kirtipur, Kathmandu, Nepal \\ ${ }^{3}$ Department of Chemistry, Tri-Chandra Multiple Campus, Tribhuvan University, Ghantaghar, \\ Kathmandu, Nepal \\ "Email: ganbajracharya@yahoo.com (G. B. Bajracharya); ramnarayan jha@yahoo.co.in (R. N. Jha)
}

Article Information:

Received: September 15, 2020

Accepted: June 7, 2021

Keywords:

Acetylation

Antibacterial

Antioxidant

Chrysophanol

Friedel-Crafts reaction

\begin{abstract}
Antioxidant and antibacterial activities of natural anthraquinones namely chrysophanol (1) and emodin (2), and synthesized anthraquinones viz. 2methylanthraquinone (3), anthraquinone (4), 2-bromoanthraquinone (5), rubiadin (6), chrysophanol diacetate (7), rubiadin diacetate (8) and 1,8-dimethoxy-3methylanthraquinone (9) were investigated. Anthraquinones 9, 3, 6, 5 and 2 exhibited a high $\mathrm{DPPH} \bullet$ radical scavenging capacity $\left(\mathrm{IC}_{50}=<500 \mu \mathrm{g} / \mathrm{mL}\right)$ showing their therapeutic potentiality for the treatment of cancers. These anthraquinones 1-9 have also displayed a weak to moderate antibacterial activity against Bacillus subtilis. Chrysophanol diacetate (7) including emodin (2) have been appeared as the valuable antibacterials.
\end{abstract}

DOI: https://doi.org/10.3126/bibechana.v18i2.31234

This work is licensed under the Creative Commons CC BY-NC License. https://creativecommons.org/licenses/by-nc/4.0/

\section{Introduction}

Anthraquinones are important members of the quinone family that have profound therapeutic values as antibacterial, antifungal, anticancer, antioxidant, laxative, diuretic, estrogenic, antiinflammatory, antiarthritic, etc. [1-3]. Anthraquinone structural motif is present in many natural dyes, pigments, vitamins, enzymes etc [4]. Among 700 natural anthraquinones identified, about 200 compounds were isolated from plants and remaining from lichens, fungi and others [5-6].
Anthraquinones are widely distributed in Aloe species of Liliaceae, Semen cassiae and Folium sennae of Leguminosae, Radix rubiae of Rubiaceae, Cascara sagrada of Rhamnaceae, and also widely exist in a number of species of Polygonaceae family especially in the genuses Rheum, Rumex and Polygonum. They are more commonly available in the important herbs like Rheum officinale, Polygonum cuspidatum, Polygonum multiflorum and Polygonum bistorta.

Antioxidant molecules inhibit oxidation of other compounds. Reactive free radicals, particularly 
reactive oxygen species such as superoxide $\left(\mathrm{O}_{2}{ }^{--}\right)$, hydroxyl $\left(\mathrm{HO}^{\circ}\right)$, peroxyl $\left(\mathrm{RO}_{2}{ }^{\circ}\right)$ and nitric oxide $\left(\mathrm{NO}^{*}\right)$, are produced in living organisms during metabolisms. An imbalance between the production of such free radicals and inability of the body to eliminate them through the use of endogenous and exogenous antioxidants result oxidative stress [7]. Oxidative stress causes oxidative damage which eventually leads to a large number of diseases including cancers, mutagenesis, cardiovascular diseases, neurodegenerative diseases (e.g. Alzheimer's and Parkinson's diseases), immunodeficiency syndrome, diabetes, cellular aging, etc [8-10].

The important reaction used for the laboratory preparation of anthraquinones is Friedel-Crafts acylation between phthalic anhydrides and benzene derivatives. In conventional two steps process, $o$ aroylbenzoic acids are first prepared in the presence of $\mathrm{AlCl}_{3}$ by the Friedel-Crafts acylation [11]. In the second step, intramolecular condensation of aryl and $o$-aroylbenzoic acid is performed to produce anthraquinones using $\mathrm{H}_{2} \mathrm{SO}_{4}$ or oleum [12], benzoyl chloride and concentrated $\mathrm{H}_{2} \mathrm{SO}_{4}$ [13-14], benzoyl chloride and $\mathrm{ZnCl}_{2}$ [15], $\mathrm{POCl}_{3}$ and $\mathrm{P}_{2} \mathrm{O}_{3} \mathrm{Cl}_{4}$ [16], or $\mathrm{B}\left(\mathrm{HSO}_{4}\right)_{3}$ [17]. A eutectic mixture of $\mathrm{AlCl}_{3}$ and $\mathrm{NaCl}$ melt has also been used to prepare various anthraquinones by the FriedelCrafts acylation between phthalic anhydrides and benzene derivatives [18-19]. Montmorillonite K10 clay [20], alum $\left(\mathrm{KAl}\left(\mathrm{SO}_{4}\right)_{2} .12 \mathrm{H}_{2} \mathrm{O}\right)$ [4] and $\mathrm{M}^{\mathrm{IV}} \mathrm{PWs}\left(\mathrm{M}^{\mathrm{IV}}=\mathrm{Zr}\right.$, Ti and $\mathrm{Sn}$; and $\mathrm{PW}=$ phosphotungstate) [21] as heterogeneous solid catalysts have also been explored, but these catalyst are not easily available.

The synthesis of anthraquinones has received a great attention in the recent past due to their therapeutic values as well as synthetic challenges. Total syntheses of some complex anthraquinones such as uncialamycin [22], dynemicin A [23], daunomycin [24], marmycin A [25], ( \pm )brasiliquinone B [26], etc. have been reported (Figure 1). Synthesis of these bioactive complex molecules requires multiple steps and are therefore available in poor quantities diminishing their therapeutic usefulness. Hence, our researches focus on isolation and/or synthesis of simple organic molecules and/or their derivatives (which can be easily obtained and/or synthesized in a large quantity) possessing remarkable medicinal values [27-31]. Recently, we have reported isolation of two anthraquinones viz. chrysophanol (1) and emodin (2) from the rhizomes of Rheum australe (Figure 1) [32]. Herein, we studied antioxidant capacity of these anthraquinones $\mathbf{1 - 2}$ as well as some newly synthesized anthraquinones 3-9. Antibacterial activity of the anthraquinones 1-9 is also screened against 6 bacterial strains.

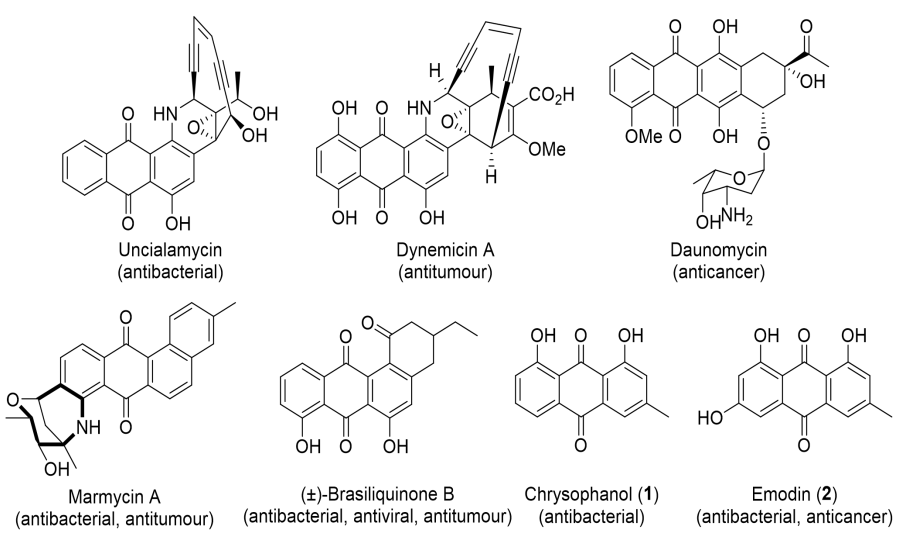

Fig. 1: Structures of some anthraquinones with their medicinal values.

\section{Experimental}

\section{Chemicals and equipments}

2,2-Diphenyl-1-picrylhydrazyl (DPPH) was procured from Sigma-Aldrich. Gallic acid was purchased from Sisco. Analytical thin layer chromatography (TLC) was performed on $0.2 \mathrm{~mm}$ pre-coated Kieselgel $60 \mathrm{~F}_{254}$ plate (E. Merck). Melting points (Mp) were determined by using a Thile's tube and are uncorrected. UV-Vis spectra were recorded on Cary 60 UV-Visible Spectrophotometer (Agilent). Spectrophotometry was carried out by using an Elisa microplate reader (EPOCH2, BioTek Instruments). IR spectra were recorded on IR Tracer-100 (Shimadzu) in KBr disc. 
Previously isolated chrysophanol (1) and emodin (2) were also used in this work [32].

\section{Procedures for the synthesis of anthraquinones}

Method 1. Friedel-Crafts and intramolecular condensation reactions to synthesize anthraquinones 3-5

Two-steps reaction protocol was followed to synthesize anthraquinones 3-5 [11-12]. Briefly, phthalic anhydride (1.48 g, $10 \mathrm{mmol})$ and a benzene derivative $(10 \mathrm{~mL}$ of either toluene, benzene or bromobenzene) were taken in a twonecked round bottom flask equipped with a magnetic stirrer, condenser, recovery bend and receiver adapter (that immersed in water containing conical flask). The content was stirred at $0{ }^{\circ} \mathrm{C}$ and then introduced $\mathrm{AlCl}_{3}(3.07 \mathrm{~g}, 23 \mathrm{mmol})$ slowly. The reaction mixture was refluxed at $90{ }^{\circ} \mathrm{C}$ until the vapour of $\mathrm{HCl}$ was ceased. Completion of the reaction was monitored by TLC (silica gel, hexane:EtOAc, 1:1). After cooling, the reaction mixture was decomposed by addition of ice water and $3 \mathrm{M} \mathrm{HCl}(25 \mathrm{~mL})$. The content was extracted with $\mathrm{Et}_{2} \mathrm{O}(20 \mathrm{~mL} \times 3)$, washed with dil. $\mathrm{HCl}$, dried over $\mathrm{Na}_{2} \mathrm{SO}_{4}$ and filtered. The solvent was evaporated and the obtained residue was vacuum dried. In the second step, dried intermediate product was refluxed with conc. $\mathrm{H}_{2} \mathrm{SO}_{4}(10 \mathrm{~mL})$ at $100{ }^{\circ} \mathrm{C}$ for 1.5 hours. After cooling, ice water was added slowly to decompose the reaction mixture and then filtered. The residue on the filter paper was washed with $32 \% \quad \mathrm{NH}_{3}$ solution until neutralization followed by water. Pure anthraquinones 3-5 were obtained after recrystallization using EtOH.

Method 2. $\mathrm{AlCl}_{3}: \mathrm{NaCl}$ melt method to synthesize anthraquinone 6

Anhydrous $\mathrm{AlCl}_{3}(13.33 \mathrm{~g}, 100 \mathrm{mmol})$ and $\mathrm{NaCl}$ $(5.32 \mathrm{~g}, 91 \mathrm{mmol})$ were taken in a $500 \mathrm{~mL}$ round bottom flask and were melted at $125-130{ }^{\circ} \mathrm{C}$. To this was added a mixture of phthalic anhydride (2.66 g, $18 \mathrm{mmol})$ and 2-methyl resorcinol $(2.23 \mathrm{~g}$, $18 \mathrm{mmol}$ ) in a small portion at a time. Now the reaction temperature was raised to $165-175{ }^{\circ} \mathrm{C}$ and stirred for 30 minutes. Thereafter, additional $\mathrm{AlCl}_{3}$ (13.33 g, $100 \mathrm{mmol})$ was added and stirring was continued for another 30 minutes. A red solid product was formed, which was decomposed by addition of ice water $(125 \mathrm{~mL})$ and conc. $\mathrm{HCl}(125$ $\mathrm{mL})$ after cooling. The reaction mixture was extracted with $\mathrm{Et}_{2} \mathrm{O}(100 \mathrm{~mL} \times 3)$. The etherial layer was washed with dil. $\mathrm{HCl}$, dried over $\mathrm{Na}_{2} \mathrm{SO}_{4}$, filtered and concentrated. The residue obtained was purified by flash silica gel column chromatography using mixtures of hexane/EtOAc to give rubiadin 6 .

\section{Method 3. Acetylation reaction to synthesize anthraquinones 7 and 8}

A mixture of chrysophanol (1) (0.254 g, $1 \mathrm{mmol})$, acetic anhydride (3.66 mL, $38.8 \mathrm{mmol})$ and pyridine $(3.5 \mathrm{~mL}, 44 \mathrm{mmol})$ was stirred at room temperature for 4 hours. Thereafter, ice cooled water was added dropwise to the reaction mixture for the precipitation. The precipitate was collected by filtration and the acetylated product 7 was purified by silica gel column chromatography using mixtures of hexane/EtOAc. To prepare anthraquinone 8, instead of chrysophanol (1), rubiadin (6) $(0.254 \mathrm{~g}, 1 \mathrm{mmol})$ was used as the starting material for the acetylation reaction.

\section{Method 4. Methylation reaction to synthesize anthraquinone 9}

A mixture of chrysophanol (1) $(0.127 \mathrm{~g}, 0.5 \mathrm{mmol})$, $\mathrm{K}_{2} \mathrm{CO}_{3}(0.760 \mathrm{~g}, 5.5 \mathrm{mmol}),\left(\mathrm{CH}_{3}\right)_{2} \mathrm{SO}_{4}(0.7 \mathrm{~mL}, 7$ $\mathrm{mmol})$ and dry acetone $(100 \mathrm{~mL})$ were taken in a round bottom flask equipped with a reflux condenser and $\mathrm{CaCl}_{2}$ guard tube. The reaction mixture was refluxed for 4 hours. Thereafter, the reaction mixture was cooled, filtered and concentrated. Thus obtained residue was purified by silica gel column chromatography using mixtures of hexane/EtOAc to afford anthraquinone 9.

\section{Analytical data of the synthesized anthraquinones}

All the synthesized anthraquinones 3-9 were analyzed by recording of $\mathrm{Mp}, \mathrm{UV}-\mathrm{Vis}$ spectra and 
FT-IR spectra, and the data were compared with the available literature.

2-Methylanthraquinone; 2-methylanthracene-9,10dione (3): Method 1. Yellow solid. Yield $1.58 \mathrm{~g}$, $71.1 \%$ in two steps. Mp $176{ }^{\circ} \mathrm{C}$ (reported 176-178 $\left.{ }^{\circ} \mathrm{C}\right)[4] . \mathrm{UV}-\mathrm{V}$ is $(\mathrm{MeOH}) \lambda_{\max } \mathrm{nm}: 328,275(\mathrm{~s}), 256$, 206. IR (KBr) $v \mathrm{~cm}^{-1}$ : $3000(\mathrm{C}-\mathrm{H}$ aromatic), 2950 $(\mathrm{C}-\mathrm{H}$ alkyl), $1720(\mathrm{C}=\mathrm{O}), 1700(\mathrm{C}=\mathrm{O}), 1575(\mathrm{C}=\mathrm{C}$ aromatic), 1285 (C-H bend) [33].

Anthraquinone; anthracene-9,10-dione (4): Method 1. Yellow solid. Yield $1.64 \mathrm{~g}, 78.8 \%$ in two steps. Mp $280{ }^{\circ} \mathrm{C}$ (reported $283-287{ }^{\circ} \mathrm{C}$ ) [34]. UV-Vis (MeOH) $\lambda_{\max } \mathrm{nm}: 325,271(\mathrm{~s}), 251,204$ [35]. IR $(\mathrm{KBr}) \vee \mathrm{cm}^{-1}: 1700(\mathrm{C}=\mathrm{O}), 1590(\mathrm{C}=\mathrm{C}$ aromatic $)$, 1350, 1325 (C-H bend) [36].

2-Bromoanthraquinone; 2-bromoanthracene-9,10dione (5): Method 1. Colourless solid. Yield 2.26 g, $78.7 \%$ in two steps. Mp $203{ }^{\circ} \mathrm{C}$ (reported 205-206 $\left.{ }^{\circ} \mathrm{C}\right)$ [4]. UV-Vis $(\mathrm{MeOH}) \lambda_{\max } \mathrm{nm}: 283,228,205$. IR $(\mathrm{KBr}) \vee \mathrm{cm}^{-1}$ : $1750(\mathrm{C}=\mathrm{O}), 1600(\mathrm{C}=\mathrm{O}), 1525$ $(\mathrm{C}=\mathrm{C}$ aromatic $), 1250 \quad(\mathrm{C}-\mathrm{H}$ bend $), 810(\mathrm{C}-\mathrm{Br}$ stretch), 500 [33].

Rubiadin; 1,3-dihydroxy-2-methylanthraquinone; 1,3-dihydroxy-2-methylanthracene-9,10-dione (6): Method 2. Yellow needles. Yield $2.35 \mathrm{~g}, 51.4 \%$. Mp $280{ }^{\circ} \mathrm{C}$ (reported 281-282 ${ }^{\circ} \mathrm{C}$ ) [37]. UV-Vis $(\mathrm{MeOH}) \lambda_{\max } \mathrm{nm}: 389,256,221 . \mathrm{IR}(\mathrm{KBr}) v \mathrm{~cm}^{-1}$ : $3450(-\mathrm{OH}), 2950(\mathrm{C}-\mathrm{H}$ alkyl), $1750(\mathrm{C}=\mathrm{O}), 1650$ $(\mathrm{C}=\mathrm{O}), 1350\left(-\mathrm{CH}_{3}\right)$ [38].

Chrysophanol diacetate; 3-methyl-9,10-dioxo-9,10dihydroanthracene-1,8-diyl diacetate (7): Method 3. Yellow needles. Yield 0.210 g, 62.1\%. Mp $204{ }^{\circ} \mathrm{C}$. UV-Vis $(\mathrm{MeOH}) \lambda_{\max } \mathrm{nm}: 428,285(\mathrm{~s}), 256,223$, 202. IR (KBr) $v \mathrm{~cm}^{-1}: 3000$ (C-H alkyl), 1750 (two coalescence peaks, $\mathrm{C}=\mathrm{O}), 1670(\mathrm{C}=\mathrm{O}), 1650$ $(\mathrm{C}=\mathrm{O}), 1600(\mathrm{C}=\mathrm{C}$ aromatic $), 1300,1275(\mathrm{C}-\mathrm{H}$ bend) (Figure 2A).

Rubiadin diacetate; 2-methyl-9,10-dioxo-9,10dihydroanthracene-1,3-diyl diacetate (8): Method 3. Yellow needles. Yield $0.20 \mathrm{~g}, 59.1 \%$. Mp $164{ }^{\circ} \mathrm{C}$. UV-Vis $(\mathrm{MeOH}) \lambda_{\max } \mathrm{nm}: 415,277,244,204$. IR $(\mathrm{KBr}) \vee \mathrm{cm}^{-1}: 2975(\mathrm{C}-\mathrm{H}$ alkyl $), 1755(\mathrm{C}=\mathrm{O}), 1750$ $(\mathrm{C}=\mathrm{O}), 1680(\mathrm{C}=\mathrm{O}), 1630(\mathrm{C}=\mathrm{O}), 1370\left(-\mathrm{CH}_{3}\right)$, 1275 (C-H bend), 1200 (Figure 2B).
1,8-Dimethoxy-3-methylanthraquinone; $\quad 1,8$ dimethoxy-3-methylanthracene-9,10-dione (9): Method 4. Yellow solid. Mp. $193{ }^{\circ} \mathrm{C}$ (reported 195 $\left.{ }^{\circ} \mathrm{C}\right)$ [39-40]. Yield $0.116 \mathrm{~g}, 82.2 \%$. UV-Vis $(\mathrm{MeOH})$ $\lambda_{\max } \mathrm{nm}: 338,256,206$. IR (KBr) $v \mathrm{~cm}^{-1}: 2950(\mathrm{C}-$ $\mathrm{H}$ alkyl), $1650(\mathrm{C}=\mathrm{O}), 1325(\mathrm{C}=\mathrm{C}$ aromatic $), 1275$, 1230, 1010 (C-O alkoxy), 955 (C-O alkoxy).

\section{Antioxidant capacity: DPPH• radical scavenging assay}

The DPPH • radical solution (concentration $0.1 \mathrm{mM}$ ) was prepared by overnight stirring of $3.9 \mathrm{mg}$ of DPPH in methanol $(100 \mathrm{~mL})$ at $4{ }^{\circ} \mathrm{C}$. Four working solutions of $25,50,250$ and $500 \mu \mathrm{g} / \mathrm{mL}$ concentrations were prepared for each anthraquinone sample. To $0.5 \mathrm{~mL}$ of the working solution, $2.5 \mathrm{~mL}$ of the $\mathrm{DPPH} \cdot$ radical solution was added. Control was prepared by adding $2.5 \mathrm{~mL}$ of the DPPH $\bullet$ radical solution in methanol $(0.5 \mathrm{~mL})$. The solutions were mixed well and were kept in dark at room temperature for 30 minutes. The absorbance was measured at $517 \mathrm{~nm}$ against blank solution consisting water $(0.5 \mathrm{~mL})$ and $\mathrm{MeOH}(2.5$ $\mathrm{mL})$. The inhibition percentage at different concentrations was calculated by using the equation shown below. Statistical analysis was done by using Microsoft excel program.

$\mathrm{DPPH} \bullet$ scavenging rate $(\%)=1-\frac{\text { Absorbance (sample) }}{\text { Absorbance (control) }} \times 100$

\section{Antibacterial activity: Agar well diffusion assay}

Three gram-positive bacteria viz. Bacillus subtilis, Staphylococcus aureus (ATCC 25952), Enterococcus faecalis, and three gram-negative bacteria viz. Klebsiella pneumoniae (ATCC 13883), Pseudomonas aeruginosa (ATTCC 27853) and Salmonella typhimurium (ATCC 14028) were used for the antibacterial assay. These bacterial strains were obtained from National Endemic Health Care Centre, Teku, Kathmandu, Nepal. The pure bacterial cultures were streaked in the nutrient agar slants for sub-culture. Thus developed each pathogenic bacterium were transferred into a separate nutrient broth by a sterile loop and incubated at $37{ }^{\circ} \mathrm{C}$ for 24 hours. 
Stock sample solutions of each anthraquinone were prepared by dissolving $0.01 \mathrm{~g}$ of the sample in 1 $\mathrm{mL}$ of DMSO (concentration $10 \mathrm{mg} / \mathrm{mL}$ ). Now, the sample solutions ( $50 \mu \mathrm{L}$ of each) were charged into the $6 \mathrm{~mm}$ wells bored on agar plates. DMSO was used as negative control. Gentamycin $(10 \mu \mathrm{g} /$ dics $)$ was used as positive control. The plates were then incubated at $37{ }^{\circ} \mathrm{C}$ for 24 hours, and the zone of inhibition (ZOI) produced was measured.

\section{Results and Discussion}

\section{Anthraquinones synthesis}

Following the known protocols, anthraquinones 3-6 were synthesized by the Friedel-Crafts acylation reaction between phthalic anhydride and benzene derivatives (toluene, benzene, bromo benzene or 2methyl resorcinol). For the synthesis of anthraquinones 3-5, a two-steps protocol - the Friedel-Crafts reaction using $\mathrm{AlCl}_{3}$ followed by $\mathrm{H}_{2} \mathrm{SO}_{4}$-mediated intramolecular condensation - was used (Scheme 1) [11-12]. Anthraquinone 6 was prepared in a single-step by the Friedel-Crafts acylation reaction between phthalic acid and 2methyl resorcinol using $\mathrm{AlCl}_{3}: \mathrm{NaCl}$ melt following a known procedure (Scheme 2) [38]. Synthesis of anthraquinones 3-6 were confirmed by comparing $\mathrm{Mp}, \mathrm{UV}-\mathrm{V}$ is spectra and IR spectra reported in the literature.

Phenols are commonly acetylated with acetic anhydride in the presence of pyridine [41]. Acetylations of previously isolated chrysophanol (1) and newly synthesized rubiadin (6) were thus performed under un-optimized conditions to afford the corresponding acetyl derivatives $\mathbf{7}$ and $\mathbf{8}$ in $62.1 \%$ and $59.1 \%$ yields, respectively (Scheme 3). In the IR spectrum of compound 7, disappearance of a broad peak of the hydroxyl group that appeared in the IR spectrum of chrysophanol (1) at $3420 \mathrm{~cm}^{-}$ ${ }^{1}$, and appearance of two coalescence peaks at 1750 $\mathrm{cm}^{-1}$ and two sharp peaks at 1670 and $1650 \mathrm{~cm}^{-1}$ for four $\mathrm{C}=\mathrm{O}$ groups confirmed its synthesis (Figure 2A). In a similar way, rubiadin (6) had peaks at $3450(-\mathrm{OH}), 1750(\mathrm{C}=\mathrm{O})$ and $1650(\mathrm{C}=\mathrm{O})$ in the IR spectrum. On the other hand, its acetyl derivative 8 showed disappearance of the hydroxyl group peak and appearance of the two additional carbonyl peaks (all together four $\mathrm{C}=\mathrm{O}$ groups at 1755,1750 , 1680 and $1630 \mathrm{~cm}^{-1}$ ) confirmed its formation (Figure 2B).

\section{Scheme 1}

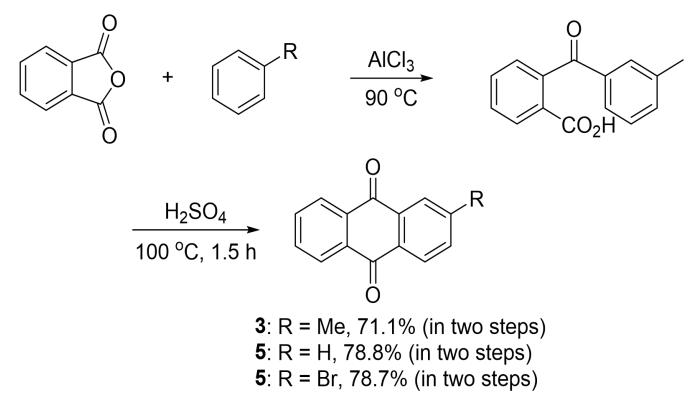

\section{Scheme 2}

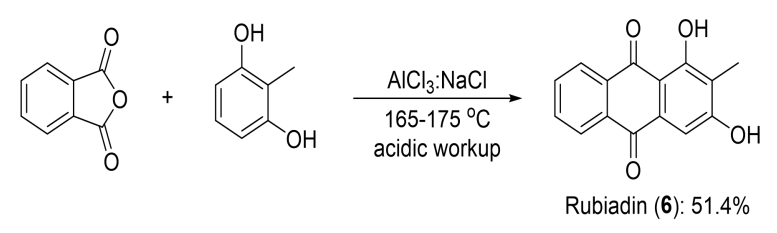

\section{Scheme 3}
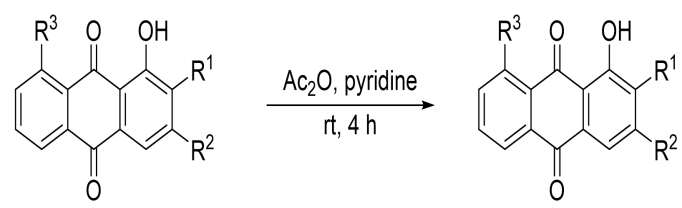

Chrysophanol (1): $R^{1}=H, R^{2}=M e, R^{3}=O H \quad 7: R^{1}=H, R^{2}=M e, R^{3}=O A c ; 62.1 \%$ Rubiadin (6): $R^{1}=M e, R^{2}=O H, R^{3}=H \quad$ 8: $R^{1}=M e, R^{2}=O A c, R^{3}=H ; 59.1 \%$

\section{Scheme 4}

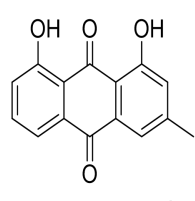

Chrysophanol (1)

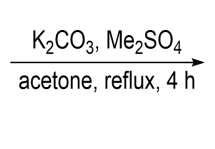

acetone, reflux, $4 \mathrm{~h}$

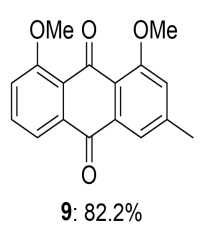

9: $82.2 \%$
Anthraquinone 9 was synthesized by following a general procedure of methylation using chrysophanol (1) as a substrate (Scheme 4) [40, 38]. Strong signals at 1010 and 955 in the IR spectrum 


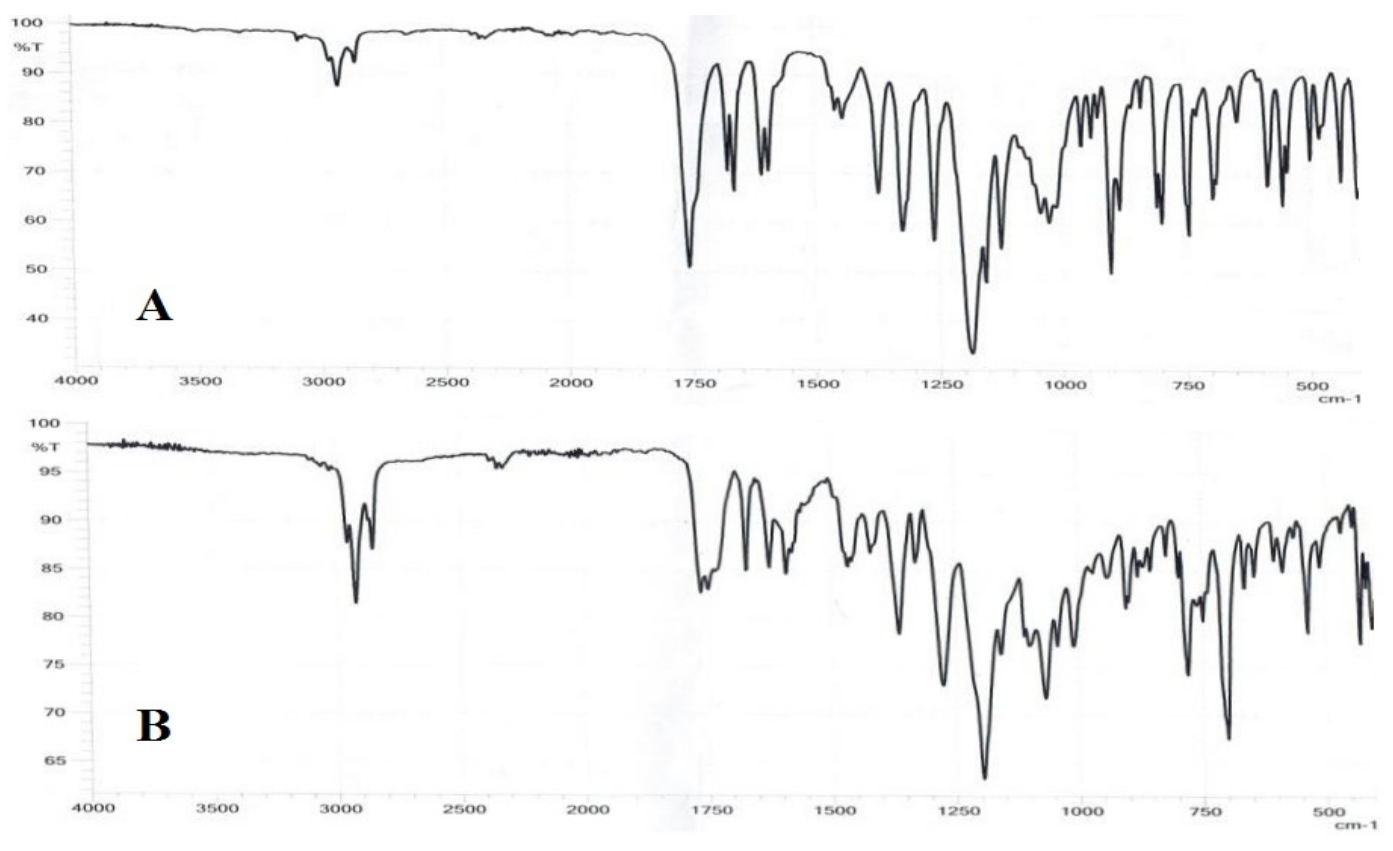

Fig. 2: (A) IR spectrum of chrysophanol diacetate (7); (B) IR spectrum of rubiadin diacetate (8).

of compound 9 were due to the two $\mathrm{C}-\mathrm{O}$ stretches of newly formed methoxy groups.

\section{Antioxidant capacity}

Recently, we have reported isolation and identification of chrysophanol (1) and emodin (2) from the rhizomes of $R$. australe [32]. Chrysophanol (1) is known as an antioxidant [42]; however, it shows no significant effect on the inhibition of cancer cell proliferation [43]. On the other hand, Zhang et al. have reported that it is effective against MCF-7 breast cancer, 7901 gastric cancer, A375 melanoma and SKOV-3 oophoroma cells [44]. Emodin (2) has more effectively inhibited the proliferation of ovarian, breast, lung, liver and prostate cancer cells [45-47]. More recently, we have studied structure-activity relationship study of quercetin derivatives in the $\mathrm{DPPH} \bullet$ radical scavenging capacity, and reported the substituent(s) effect [27]. Since anthraquinones are known for various biological activities including antioxidant and anticancer activities, we were encouraged to synthesize a number of anthraquinones for the screening of their antioxidant potentiality. Thus in the present work, we have synthesized anthraquinones 3-9 and together with previously isolated chrysophanol (1) and emodin (2) were used to determine the antioxidant potentiality using the DPPH assay [48].

By using the experimental absorbance values obtained in the DPPH assay, linear curves of percentage inhibition versus concentration for every anthraquinone were plotted and then $\mathrm{IC}_{50}$ values were computed. The result of DPPH assay is depicted in Figure 3. As can be seen in the figure, 1,8-dimethoxy-3-methylanthraquinone (9) is the most potent antioxidant $\left(\mathrm{IC}_{50}=200 \mu \mathrm{g} / \mathrm{mL}\right)$ among other anthraquinones tested, followed by 2methylanthraquinone (3) $\left(\mathrm{IC}_{50}=230 \mu \mathrm{g} / \mathrm{mL}\right)$, rubiadin (6) $\left(\mathrm{IC}_{50}=259 \mu \mathrm{g} / \mathrm{mL}\right)$, and 2bromoanthraquinone (5) $\left(\mathrm{IC}_{50}=383 \mu \mathrm{g} / \mathrm{mL}\right)$. In this study, anthraquinones $\mathbf{9 , 3}, \mathbf{6}$ and $\mathbf{5}$ were found more effective in scavenging of $\mathrm{DPPH} \bullet$ radical than emodin (2) $\left(\mathrm{IC}_{50}=400 \mu \mathrm{g} / \mathrm{mL}\right)$, which has displayed anticancer activity in several studies [4547]. Rubiadin (6) has shown anticancer activity in the 3-(4,5-dimethy lthiazol-2-yl )-2,5-diphenyl 


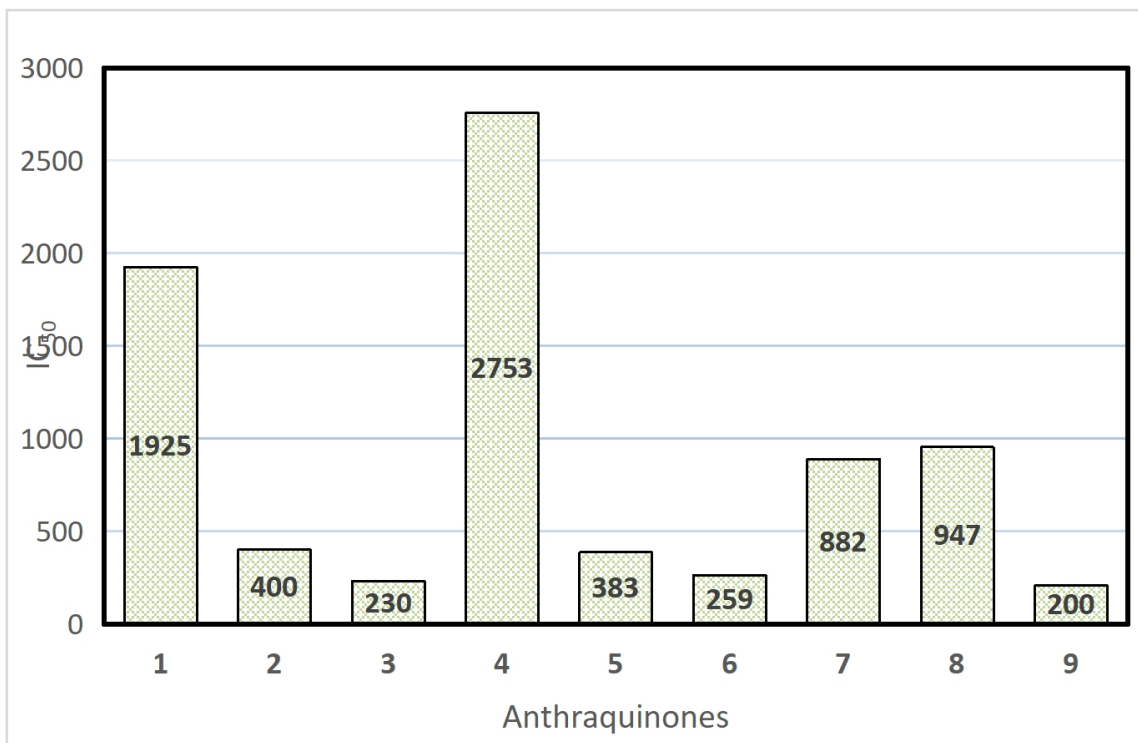

Fig. 3: $\mathrm{IC}_{50}$ values of anthraquinones (1-9) in the DPPH assay.

Table 1: Antibacterial activity of the anthraquinones 1-9.

\begin{tabular}{|c|c|c|c|c|c|c|c|c|c|c|c|}
\hline \multirow[t]{2}{*}{ S. $\mathbf{N}$. } & \multirow[t]{2}{*}{$\begin{array}{c}\text { Pathogenic } \\
\text { bacteria used }\end{array}$} & \multicolumn{10}{|c|}{$\begin{array}{l}\text { ZOI shown by different antharaquinones 1-9 and standard } \\
\qquad{\text { (in } \mathrm{mm} \text { diameter) })^{\mathrm{a}}}\end{array}$} \\
\hline & & 1 & 2 & 3 & 4 & 5 & 6 & 7 & 8 & 9 & Gentamycin \\
\hline 1 & B. subtilis & 9 & 16 & 11 & 11 & 8 & 12 & 10 & 10 & 8 & 16 \\
\hline 2 & S. aureus & - & 17 & 12 & - & - & 11 & 13 & - & - & 24 \\
\hline 3 & E. faecalis & 8 & - & - & - & - & - & 14 & - & - & 20 \\
\hline 4 & K. pneumoniae & - & - & - & 10 & - & - & 9 & - & - & 12 \\
\hline 5 & P. aeruginosa & - & - & - & - & - & - & - & - & - & 25 \\
\hline 6 & S. typhimurium & - & - & - & - & - & - & - & - & - & 18 \\
\hline
\end{tabular}

${ }^{a}$ Values of the ZOI include the diameter of well $(6 \mathrm{~mm})$ after 24 hours incubation against different bacterial species in the Agar well diffusion assay. (-)-Sign indicates no significant ZOI was observed. 
tetrazolium bromide (MTT) assay against different cancer cells (MCF7 breast cancer, MES-SA human uterine sarcoma, MES-SA/DX5 multidrug-resistant variant human uterine sarcoma, DU145 prostate cancer and H460 lung cancer cells) [37]. Chrysophanol (1) was found ineffective in scavenging of DPPH $\bullet$ radical $\left(\mathrm{IC}_{50}=1925 \mu \mathrm{g} / \mathrm{mL}\right)$. Unsubstituted anthraquinone (4) was found least effective among the others.

\section{Antibacterial activity}

The isolated and synthesized anthraquinones (1-9) were evaluated for the antibacterial activity by using the Agar well diffusion assay [49]. The ZOI produced by these compounds is tabulated in Table 1.

All investigated anthraquinones 1-9 have displayed a weak to moderate antibacterial activity against $B$. subtilis $(\mathrm{ZOI}=8-16 \mathrm{~mm})$, while all these compounds were found ineffective against $P$. aeruginosa and $S$. typhimurium. A weak antibacterial activity of chrysophanol (1) against $B$. subtilis and $S$. aureus has already been reported [50-51]. Literature search reveals that emodin (2) exhibits noticeable antibacterial activity against methicillin-resistant $S$. aureus, $P$. aeruginosa, Escherichia coli, S. typhimurium, Bacillus cereus and Shigella sonnei [52-53]. In the present study, emodin (2) was found efficient antibacterial against B. subtilis $(\mathrm{ZOI}=16 \mathrm{~mm})$ and $S$. aureus $(\mathrm{ZOI}=17$ $\mathrm{mm}$ ) in accordance with the literature, and in contrast, it was found ineffective against $P$. aeruginosa and S. typhimurium.

2-Methylanthraquinone (3) $(\mathrm{ZOI}=12 \mathrm{~mm})$ and rubiadin (6) $(\mathrm{ZOI}=11 \mathrm{~mm})$ have displayed noticeable antibacterial activity against $S$. aureus. The growth of $S$. aureus (ZOI $=13 \mathrm{~mm}), E$. faecalis $(\mathrm{ZOI}=14 \mathrm{~mm})$ and $K$. pneumoniae $(\mathrm{ZOI}=$ $9 \mathrm{~mm}$ ) was remarkably inhibited by chrysophanol diacetate (7), which clearly indicated that the biological activity of a compound can be significantly enhanced by the structural modification (compare antibacterial activity of parent chrysophanol 1 versus its diacetate derivative 7). Unsubstituted anthraquinone (4) exhibited a weak antibacterial activity against $K$. pneumoniae $(\mathrm{ZOI}=10 \mathrm{~mm})$.

\section{Conclusion}

Anthraquinones are the potential drugs used against different diseases. We have synthesized a number of anthraquinones using known protocols, and evaluated their antioxidant and antibacterial activities. DPPH $\bullet$ radical scavenging capacity of 1,8-dimethoxy-3-methylanthraquinone (9), 2methylanthraquinone (3), rubiadin (6) and 2bromoanthraquinone (5) were found comparatively more effective than emodin (2), a well-known compound for its anticancer activity. Hence these compounds warrant further cancer cell lines studies. In addition, anthraquinones 1-9 have shown a weak to moderate antibacterial activity against $B$. subtilis, while they were found ineffective against $P$. aeruginosa and $S$. typhimurium. Interestingly, a significant enhancement in the antibacterial activity was observed in chrysophanol diacetate (7) as compared to its parent compound $\mathbf{1}$, which is a known compound with a weak antibacterial activity.

\section{Acknowledgments}

This work was supported by Nepal Academy of Science and Technology (NAST). R.K.G. acknowledges NAST-University Collaborative Research Program for a Ph.D. fellowship.

\section{References}

[1] M. Fouillaud, Y. Caro, M. Venkatachalam, I. Grondin, L. Dufossé, Anthraquinones, Phenolic Compounds in Food: Characterization and Analysis (L. M. L. Nollet, J. A. Gutiérrez-Uribe, Eds.), CRC Press, Boca Raton, FL (2018) pp. 130170.

https://hal.univ-reunion.fr/hal-01657104

[2] G. Diaz-Muñoz, I. L. Miranda, S. K. Sartori, D. C. de Rezende, M. A. N. Diaz, Anthraquinones: an overview, Studies in Natural Products Chemistry, Volume 58 (A. Rahman, Ed.), Elsevier Science and Technology, Oxford, UK (2018). https://doi.org/10.1016/B978-0-444-64056-7.00011-8

[3] E. Haciosmanoglu, F. Ozkok, A. K. Onsu, M. 
Bektas, B. Varol, S. Pehlivan, Synthesis of new anthraquinone derivatives and anticancer effects on breast cancer cell lines, Eurasia Proceed. Sci. Technol. Eng. Math. 4 (2018) 271-276. https://dergipark.org.tr/en/pub/epstem/issue/40805/ $\underline{498144}$

[4] B. R. Madje, K. F. Shelke, S. B. Sapkal, G. K. Kakade, M. S. Shingare, An efficient one-pot synthesis of anthraquinone derivatives catalyzed by alum in aqueous media, Green Chem. Lett. Rev. 3 (2010) 269-273.

http://dx.doi.org/10.1080/17518251003776877

[5] J. Duval, V. Pecher, M. Poujol, E. Lesellier, Research advances for the extraction, analysis and uses of anthraquinones: a review, Ind. Crop. Prod. 94 (2016) 812-833. http://dx.doi.org/10.1016/j.indcrop.2016.09.056

[6] D. S. Seigler, Plant Secondary Metabolism, Springer Science and Business Media, New York (2012).

[7] N. F. Santos-Sánchez, R. Salas-Coronado, C. Villanueva-Cañongo, B. HernándezCarlos, Antioxidant compounds and their antioxidant mechanism, IntechOpen (2019). http://dx.doi.org/10.5772/intechopen.85270

[8] K. E. Heim, A. R. Tagliaferro, D. J. Bobilya, Flavonoid antioxidants: chemistry, metabolism and structure-activity relationships, J. Nutr. Biochem. 13 (2002) 572-584.

https://doi.org/10.1016/S0955-2863(02)00208-5

[9] İ. Gülçin, Antioxidant activity of food constituents: an overview, Arch. Toxicol. 86 (2012) 345-391. https://doi.org/10.1007/s00204-011-0774-2

[10] J. Emerit, M. Edeas, F. Bricaire, Neurodegenerative diseases and oxidative stress, Biomed. Phrmacother. 58 (2004) 39-46. https://doi.org/10.1016/j.biopha.2003.11.004

[11] L. F. Fieser, p-Toluyl-o-benzoic acid, Org. Synth. 4 (1925) 73; Org. Synth. Coll. 1 (1941) 517. https://doi.org/10.15227/orgsyn.004.0073

[12] L. F. Fieser, $\beta$-methylanthraquinone, Org. Synth. 4 (1925), 43; Org. Synth. Coll. 1 (1941) 353. https://doi.org/10.15227/orgsyn.004.0043

[13] E. Clar, Das kondensationsprinzip ein einfaches neues prinzip im Aufbau der aromatischen kohlenwasserstoffe (Aromatische kohlenwassertoffe XLII. Mitteilung), Chem. Ber. 81 (1948) 52-63. https://doi.org/10.1002/cber.19480810110

[14] E. Clar, Aromatic hydrocarbons. Part LIII. 7:8-
Benzheptaphene, J. Chem. Soc. (1949) 2440-2442. https://doi.org/10.1039/JR9490002440

[15] E. Clar, Eine neue synthese des naphtho-(2'.3':3.4)-pentaphens (Aromatische kohlenwasserstoffe XLVI. Mitteilung), Chem. Ber. 81(1948)169-175. https://doi.org/10.1002/cber.19480810215

[16] S. El-Sayrafi, S. Rayyan, Intramolecular acylation of aryl- and aroyl-aliphatic acids by the action of pyrophosphoryl chloride and phosphorus oxychloride, Molecules 6 (2001) 279-286. https://doi.org/10.3390/60300279

[17] B. R. Madje, M. B. Ubale, J. V. Bharad, M. S. Shingare, $\mathrm{B}\left(\mathrm{HSO}_{4}\right)_{3}$ : an efficient solid acid catalyst for the synthesis of anthraquinone derivatives. Bull. Catal. Soc. India 9 (2011) 19-25.

[18] Z. I. Horii, H. Hakusui, T. Momose, Synthetic studies on anthracyclinones. VII. Synthesis of bisanhydroaklavinone, Chem. Pharm. Bull. 16 (1968) 1262-1265. https://doi.org/10.1248/cpb.16.1262

[19] B. L. Wei, S.H. Wu, M. I. Chung, S. J. Won, C. N. Lin, Synthesis and cytotoxic effect of 1,3dihydroxy-9,10-anthrquinone derivatives. European J. Med. Chem. 35 (2000) 1089-1098. https://doi.org/10.1016/S0223-5234(00)01190-9

[20] U. Hofmann, On the chemistry of clay, Angew. Chem. Int. Ed. 7 (1968) 681-692. https://doi.org/10.1002/anie.196806811

[21] U. V. Chudasama, S. V. Ghodke, T. F. Parangi, Green routes to synthesis of anthraquinone derivatives via Friedel-Crafts reaction under solvent free conditions using solid acid catalyst, Intl. J. Eng. Res. Sci. Technol. 4 (2015) 97-115. http://www.ijerst.com/currentissue.php

[22] K. C. Nicolaou, H. Zhang, J. S. Chen, J. J. Crawford, L. Pasunoori, Total synthesis and stereochemistry of uncialamycin, Angew. Chem. Int. Ed. $46 \quad$ (2007) 4704-4707. https://doi.org/10.1002/anie.200700917

[23] M. D. Shair, T. Y. Yoon, S. J. Danishefsky, Total synthesis of $( \pm)$-dynemicin A, Angew. Chem. Int. Ed. $\quad 34 \quad$ (1995) 1721-1723. https://doi.org/10.1002/anie.199517211

[24] K. A. Parker, J. Kallmerten, Efficient, regiospecific synthesis of anthracycline intermediates: total synthesis of daunomycin, J. Am. Chem. Soc. 102 (1980)5881-5886. https://doi.org/10.1021/ja00538a029

[25] T. Cañeque, F. Gomes, T. T. Mai, F. Blanchard, P. Retailleau, J. F. Gallard, G. Maestri, M. Malacria, 
R. Rodriguez, A synthetic study towards the marmycins and analogues, Synthesis 49 (2017) 587-592.

https://doi.org/10.1055/s-0035-1562627

[26] M. L. Patil, H. B. Borate, D. E. Ponde, B. M. Bhawal, V. H. Deshpande, First total synthesis of ( \pm )-brasiliquinone B, Tetrahedron Lett. 40 (1999) 4437-4438.

https://doi.org/10.1016/S0040-4039(99)00766-2

[27] G. B. Bajracharya, M. Paudel, R. K. C., S. L. Shyaula, Structure-activity relationship and MM2 energy minimized conformational analysis of quercetin and its derivatives in the $\mathrm{DPPH} \bullet$ radical scavenging capacity, Bibechana 17 (2020) 20-27. https://doi.org/10.3126/bibechana.v17i0.25208

[28] S. Thapa, G. M. S. Thakuri, P. K. C., S. L. Shyaula, G. B. Bajracharya, Chalcones bearing hydroxyl substituent in the cinnamoyl ring possess antioxidative potentiality, J. Nepal Chem. Soc. 35 (2016) 152-160.

[29] S. L. Shyaula, T. Tamang, N. Ghouri, A. Adhikari, S. Marasini, G. B. Bajracharya, M. D. Manandhar, M. I. Choudhary, Antileishmanial diterpenoid alkaloids from Aconitum spicatum (Bruhl) Stapf, Nat. Prod. Res. 30 (2016) 2590-2593. https://doi.org/10.1080/14786419.2015.1114941

[30] G. B. Bajracharya, R. Maharjan, Development of an ease methodology for the isolation of Ayurveda drug 'Bergenin', J. Nepal Chem. Soc. 32 (2013) 65-69.

[31] G. B. Bajracharya, D. B. Thapa, Quercetin as a protease ( $\alpha$-chymotrypsin) inhibitor, Nepal J. Sci. Technol. 14 (2013) 91-96.

[32] R. K. Gupta, G. B. Bajracharya, R. N. Jha, Antibacterial activity, cytotoxicity, antioxidant capacity and phytochemicals of Rheum australe rhizomes of Nepal, J. Pharmacog. Phytochem. 2 (2014)

$125-128$. http://www.phytojournal.com/vol2Issue6/Issue feb 2014/4.1.pdf

[33] H. Naeimi, S. S. Brojerdi, Facile and efficient onepot synthesis of anthraquinones from benzene derivatives catalyzed by silica sulfuric acid, Polycyclic Aromat. Compd. 34 (2014) 504-517. https://doi.org/10.1080/10406638.2014.910238

[34] http://www.chemspider.com/ChemicalStructure.13835294.html (Accessed on 12 September, 2020)

[35] V. Mohanlall, P. Steenkamp, B. Odhav, Isolation and characterization of anthraquinone derivatives from Ceratotheca triloba (Bernh.) Hook.f., J. Med.
Plants Res. $5 \quad$ (2011) 3132-3141. https://doi.org/10.5897/JMPR.9000834

[36] https://www.chemicalbook.com/SpectrumEN_8465-1 IR1.htm (accessed on 12 September, 2020)

[37] K. Saha, K. W. Lam, F. Abas, A. S. Hamzah, J. Stanslas, L. S. Hui, N. H. Lajis, Synthesis of damnacanthal, a naturally occurring 9,10anthraquinone and its analogues, and its biological evaluation against five cancer cell lines, Med. Chem. Res. 22 (2013) 2093-2104. https://doi.org/10.1007/s00044-012-0197-5

[38] M. N. Akhtar, S. Zareen, S. K. Yeap, W. Y. Ho, K. M. Lo, A. Hasan, N. B. Alitheen, Total synthesis, cytotoxic effects of damnacanthal, nordamnacanthal and related anthraquinone analogues, Molecules 18 (2013) 10042-10055. https://doi.org/10.3390/molecules 180810042

[39] von O. A. Oesterle, Ueber die chrysophansäure, Arch. Pharm. 243 (1905) 434-442. https://doi.org/10.1002/ardp.19052430233

[40] P. de Witte, J. Lemli, Synthesis of C-9- ${ }^{14} \mathrm{C}-1,8-$ dihydroxy-3-carboxyanthraquinone, J. Labelled Compd. Radiopharm. 25 (1988) 23-33. http://doi.org/10.1002/jlcr.2580250104

[41] G. B. Bajracharya, S. S. Shrestha, Unprecedented acetylation of phenols using a catalytic amount of magnesium powder, Synth. Commun. 48 (2018) 1688-1693.

https://doi.org/10.1080/00397911.2018.1459721

[42] G. C. Yen, P. D. Duh, D. Y. Chuang, Antioxidant activity of anthraquinones and anthrone, Food Chem. $\quad 70 \quad$ (2000) 437-441. https://doi.org/10.1016/S0308-8146(00)00108-4

[43] Q. Huang, G. Lu, H. M. Shen, M. C. M. Chung, C. N. Ong, Anti-cancer properties of anthraquinones from rhubarb, Med. Res. Rev. 27 (2007) 609-630. https://doi.org/10.1002/med.20094

[44] H. Zhang, Z. Guo, N. Wu, W. Xu, L. Han, N. Li, Y. Han, Two novel naphthalene glucosides and an anthraquinone isolated from Rumex dentatus and their antiproliferation activities in four cell lines, Molecules $\quad 17 \quad$ (2012) 843-850. https://doi.org/10.3390/molecules 17010843

[45] J. Li, P. Liu, H. Mao, A. Wanga, X. Zhang, Emodin sensitizes paclitaxel-resistant human ovarian cancer cells to paclitaxel-induced apoptosis in vitro, Oncol. Rep. 21 (2009) 1605-1610. doi: 10.3892/OR_00000394

[46] C. X. Yu, X. Q. Zhang, L. D. Kang, P. J. Zhang, W. W. Chen, W. W. Liu, Q. W. Liu, J. Y. Zhang, Emodin induces apoptosis in human prostate 
cancer cell LNCaP, Asian J. Androl. 10 (2008) 625-634.

https://doi.org/10.1111/j.1745-7262.2008.00397.x

[47] T. Chihara, K. Shimpo, H. Beppu, N. Yamamoto, T. Kaneko, K. Wakamatsu, S. Sonoda, Effects of aloe-emodin and emodin on proliferation of the MKN45 human gastric cancer cell line, Asian Pac. J. Cancer Prev. 16 (2015) 3887-3891. http://dx.doi.org/10.7314/APJCP.2015.16.9.3887

[48] W. Brand-Williams, M. E. Cuvelier, C. Berset, Use of a free radical method to evaluate antioxidant activity. LWT - Food Sci. Technol. 28 (1995) 2530. https://doi.org/10.1016/S0023-6438(95)80008$\underline{5}$

[49] C. P. Rodríguez, M. Paul, P. Bazerque, C. PerezEid, An antibiotic assay by the agar-well diffusion method. Acta Biologiae et Medecine Experimentalis 15 (1990) 113-115.

[50] K. García-Sosa, N. Villarreal-Alvarez, P. Lübben, L. M. Peña-Rodríguez, Chrysophanol, an antimicrobial anthraquinone from the root extract of Colubrina greggii, J. Mex. Chem. Soc. 50 (2006) 76-78. https://doi.org/10.29356/jmcs.v50i2.1306

[51] R. M. Coopoosamy, M. L. Magwa, Antibacterial activity of chrysophanol isolated from Aloe excelsa (Berger), African J. Biotechnol. 5 (2006) 1508-1510.

https://www.ajol.info/index.php/ajb/article/view/43 $\underline{147}$

[52] T. Hatano, H. Uebayashi, H. Ito, S. Shiota, T. Tsuchiya, T. Yoshida, Phenolic constituents of cassia seeds and antibacterial effect of some naphthalenes and anthraquinones on methicillinresistant Staphylococcus aureus, Chem. Pharm. Bull. $\quad 47 \quad$ (1999) 1121-1127. https://doi.org/10.1248/cpb.47.1121

[53] N. H. Lee, S. M. Lee, D. H. Song, J. Y. Yang, H. S. Lee, Antimicrobial effect of emodin isolated from Cassia tora Linn. seeds against food-borne bacteria, J. Appl. Biol. Chem. 56 (2013) 187-189. http://dx.doi.org/10.3839/jabc.2013.030 